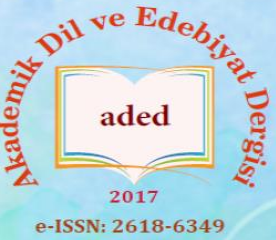

Akademik Dil ve Edebiyat Dergisi

Academic Journal of Language and Literature

Cilt/Volume: 3, Sayı/Issue: 4, (Aralık/December 2019)

USTALARA SAYGI-I:

Prof. Dr. Fatma Sabiha KUTLAR OĞUZ'a Armağan

\title{
Osmanlı Dönemi Metinlerinde Ekmek ve Ekmekle İlgili Anlam Çerçeveleri
}

\section{Bread and Its Semantic Framework in Ottoman Period Texts}

\section{İncinur ATIKK GÜRBÜZ $Z^{\star}$}

*Dr. Öğr. Üyesi, Konya Necmettin Erbakan Üniversitesi

e-mail ${ }^{*}$ incinuratik@hotmail.com

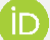

https://orcid.org/0000-0002-4551-9741

Araştırma Makalesi/Research Article

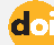

https://doi.org/10.34083/akaded.650245

Sorumlu Yazar/Corresponding Author İncinur Atik Gürbüz, Konya Necmettin Erbakan Üniversitesi, Konya/Türkiye

Geliş Tarihi/Received : 23.11.2019

Kabul Tarihi/Accepted: 09.12.2019

\section{Atıf/Citation}

ATİK GÜRBÜZ, İncinur (2019). Osmanlı Dönemi Metinlerinde Ekmek ve Ekmekle İlgili Anlam Çerçeveleri, Akademik Dil ve Edebiyat Dergisi, 3 (4), 348-376 DOI: $10.34083 /$ akaded.650245

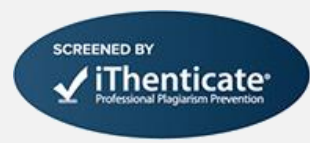

Öz

Kaynaklara göre insanoğlu, yaşaması için gerekli olan beslenme ihtiyacını ilk dönemlerde avladığı hayvanlardan elde ettiği et türevi besinlerle ve topladığı meyve ve bitki tohumları ile karşılamaktaydı. $\mathrm{Bu}$ aşamada doğanın kendisine sunduklarıyla yetinen insanoğlu elindeki malzemeyi değiştirme/dönüştürme yetisine sahip değildi. Dolayısıyla bitki tohumlarını işleyip una dönüştürmeyi de bilmiyordu. Kesin tarihi bilinmemekle birlikte insanın ateşi kullanmayı öğrenmesi ve yerleşik yaşama geçmesi, besin kaynaklarının çeşitlenmesinin önünü açtı. Bu sürecin sonunda insanoğlu tahılı işlemeyi, elde ettiği unu mayalı ya da mayasız olarak hamur hâline getirmeyi ve fırın, tandır, sac gibi aletler aracılığıyla pişirerek ekmek hâline getirmeyi de öğrendi. Ortaya çıkan bu yiyecek insanlar tarafından öylesine beğenildi ki tarihin her döneminde insanlığın en temel besin kaynaklarından biri oldu. İnsanlığın gelişim sürecinde şehirleşmeye, meslekî bölümlenmeye ve ihtisaslaşmaya paralel olarak daha kolay üretilebilir ve ulaşılabilir olmasıyla birlikte bütün dünyada kurulan her sofranın vazgeçilmezi hâline geldi.

Tarihî kayıtlarda Babil halkının fırında ekmek pişirmeyi bildiği, eski Misır'da -tesadüfen bulunan- ekmek mayalama yönteminin kullanıldığı hatta Mısır'da beyaz ekmeğin soyluların ve sarayın simgesi sayıldığı gibi bilgiler bugüne aktarılmaktadır. Türklerde ise Orta Asya'dan itibaren var olan ekmek/etmek kültürü, Anadolu'ya yerleştikten sonra çeşitlenmiş ve daha zengin bir hâle gelmiştir. Anadolu coğrafyasının buğday yönünden zengin olmasının da etkisiyle buğday başta olmak üzere çavdar, arpa, mısır gibi tahıllar, ekmek yapımında kullanılmış ve ayrıca çeşitli yapım teknikleri ile ekmeğin şekli, tadı, dayanma süreleri de belirlenmiştir.

Ekmek, toplumsal yapının gelişimiyle birlikte asgari düzeydeki beslenmenin sembolü hâline gelmiştir. İnsanların ekmeğe erişim gücü, toplumun refah düzeyinin göstereni olarak kabul edilmiştir. Toplumsal hayatın bu kadar önemli bir parçası olan ekmeğin ve çeşitlerinin, yaşanılan hayatın bir göstereni olan edebiyata ve edebi metinlere de yansıdığı görülmektedir. Bu çerçevede ekmekle ilgili pek çok unsur, edebiyatın mecazlar dünyası içerisinde kendine yer bulmuştur.

Bu makalede ekmeğin ve ekmekle ilgili unsurların Osmanlı dönemi edebî metinlerindeki kullanılış biçimleri incelenecektir. Bu inceleme sonucunda ekmek etrafında oluşan anlam çerçevelerinin tespit edilmesi hedeflenmiştir.

Anahtar Kelimeler: Klasik Türk edebiyatı, edebî metinler, ekmek, anlam çerçevesi 


\section{Bread and Its Semantic Framework in Ottoman Period Texts}

According to the resources, human beings met their essential nutritional needs with meat-derived foods obtained from the animals they hunted in the early periods as well as the fruit and plant seeds they collected. At this stage, mankind, contented with what nature offered him, did not have the ability to change/transform the material in his hand. Thus, he did not know how to process plant seeds and turn them into flour. Although the exact date is unknown, learning how to use fire and adopting a settled life paved the way for diversification of food sources. Eventually, human beings learned to process grain, to turn the resulting flour into yeast or unleavened dough and to make bread by cooking with the help of such tools as oven, tandoori, sheet metal, etc. The resulting food was so much appreciated by people that it became one of the most basic food sources of humanity in every period of history. Being more easily produced and accessible in parallel with the urbanization, occupational segmentation and specialization in the development process of humanity, it has become an indispensable part of every meal all over the world.

The historical records show that Babylonian people knew how to bake bread in the oven, that ancient Egyptians used a bread fermentation method, which was discovered by chance, and that white bread was even considered the symbol of the nobles and the palace. On the other hand, the bread/eating culture that had existed in Turks since Central Asia became more diversified and grown richer when they settled in Anatolia. Due to the richness of Anatolia in terms of wheat, cereals such as wheat (in particular), rye, barley and corn were used in bread making and also the shape, taste and durability of bread were determined with various production techniques.

With the development of social structure, bread has turned into a symbol of minimum nutrition. People's ability to access bread is accepted as an indicator of the welfare of society. It is seen that bread and its varieties, which are such an important part of social life, are also reflected in literature and literary texts as an indicator of everyday life. In this context, many bread-related elements have found their place in the world of literary metaphors.

In this article, the usage of bread and bread-related elements in Ottoman literary texts will be examined. As a result of this study, it is aimed to determine the semantic framework around the concept of bread.

Keywords: Classical Turkish literature, literary texts, bread, semantic framework 


\section{Giriş:}

Ekmek, her dönemde ve her millette sofraların vazgeçilmez unsuru olarak karşımıza çıkan temel bir besin maddesidir. Ekmeğin tarihçesi araştırıldığında, takip edilebilen tüm dönemlerden bugüne yapılabilecek en önemli tespit, herhalde ekmeğin hikâyesi ile insanoğlunun hikâyesinin birlikte başlayıp devam ettiği olacaktır ${ }^{1}$. Ekmeğin ortaya çıkışı ve gelişim seyriyle ilgili birçok inanış ve anlatı mevcuttur. Tarihsel olarak konuya bakıldığında ekmek ile ateşin bulunması ve yerleşik düzene geçme arasında bir paralellik olduğu dikkati çeker. Ekmeğin keșfi ile ilgili kabul gören en eski hikâyeye göre (bk. Kuter, 2013: 41), ateşin bulunuşunun ardından ilk insanlar su ile ıslatılmış ve kendi hâline bırakılmış buğday kırmasında gözeneklerin meydana geldiğini görmüşler ve bunun sıcak taşlar üzerinde pişirildiğinde daha lezzetli olduğunu fark etmişlerdir. Böylece insanlar ekmek tüketmeye başlamışlardır.

Yine tarihsel süreçte ekmekle ve ekmek yapımında kullanılan yöntemlerle ilgili olarak insanoğlunun çabaları hakkında bazı bilgiler de mevcuttur. Örneğin, yapılan arkeolojik çalışmalardan hareketle MÖ 4000 yıllarında Babillilerin değirmencilik ve firıncılık sanatını icra ettikleri ve fırınlarda ekmek pişirmeyi bildikleri anlaşılmaktadır. Yine çok eskiden beri ekmek yapmayı bilen Mısırlılar, MÖ. 2600 yıllarında mayalamayı keşfettikleri, buğday unu ve su karışımından elde edilen hamurun mayalandığı zaman ekmeğin daha yumuşak, daha kabarık olduğunu fark ettikleri bilinmektedir. Bundan sonra mayalanmış beyaz ekmek, Antik Mısır'da soyluların ve sarayın simgesi haline gelmiş, zenginlerin ve soyluların rağbet ettiği bu mayalı ekmekler Antik Mısır'da para yerine kullanılır olmuştur (Kuter, 2013: 43).

İslam inanışında ekmeğin tarihçesi Hz. Âdem'e dayandırılır. Bu inanışla ilgili anlatıya Seyahatnâme'de rastlamak mümkündür. Evliya Çelebi, "Ekmekçiler Esnafı" başlıklı bölümde Hz. Âdem cennetten çıkarılıp

\footnotetext{
${ }^{1}$ Önceleri avcılıkla ve toplayıcılıkla beslenen insanların bir süre sonra değișen ve çoğalan ihtiyaçlarına paralel olarak besin kaynaklarını çeşitlendirme ve böylece daha sürdürülebilir ve istikrarlı bir beslenme imkânına sahip olma çabasının sonucunda bitki tohumlarına yönelerek bunları 1slah etmesi, elde ettiği bitki tohumlarını işlemesi ve nihayetinde ekmek yapımını öğrenmesi sürecini anlatan çeşitli çalışmalar mevcuttur (Bu konuda bk. Ünsal, 2003). Ayrıca özelde Türk kültüründe ekmek üzerine de çeşitli çalışmalar yapılmıştır (Bu konuda bk. Özgüdenli ve Uzunağaç, 2014; Samanc1, 2013; Şavkay, 2000).
} 
yeryüzüne gönderilince Cebrail'in (as) yeryüzüne buğdayı getirdiğini ve Hz. Âdem'in yediği ilk yiyeceğin bu buğdaydan yapılan çorba olduğu bilgisini verir. Daha sonra Cebrail'in (as), Hz. Âdem'e buğdayı un, unu da hamur hâline getirmesini ve hamuru pişirip ekmek yapmasını öğrettiğini anlatır. $\mathrm{Bu}$ sebeple ekmekçilerin ilk pîrinin Hz. Âdem olduğunu kaydeder².

Neolitik çağlardan itibaren tarımla uğraşan Türkler de çok eski tarihlerden beri ekmek yapmayı bilmekteydiler. Nitekim Türklerin Neolitik çağdan itibaren tarım ile uğraştığı, saban, orak, hububat ezmek için yapılmış taşlar gibi araç gereçleri kullandıkları ve arpa, mısır, buğday, çavdar, yulaf, burçak gibi tahılları ektikleri bilinmektedir. Anadolu'da ise ekmek yapımı Cilalı Taş (Neolitik) devrinde Orta ve Güneydoğu Anadolu'da yaşayan avcı ve toplayıcı toplulukların yerleşmeler kurarak çiftçiliğe yönelmeleriyle başlamıştır. Orta Asya'dan gelen Türk boylarının getirdiği ekmek kültürü; Selçuklular, Türk beylikleri, ardından Osmanlı İmparatorluğu, Türkiye Cumhuriyeti'ne dek uzayan bir zaman çizgisinde Anadolu'ya komşu bölgelerin ekmek alışkanlıklarıyla iç içe geçmiştir (Kabak, 2013: 588).

Ekmek ve ekmek ile ilgili kelimelerin tarih içindeki seyrini takip edebilmenin bir yolu da ona metinlerde nasıl yer verildiğine bakmak olacaktır. Nitekim Türklerin daha Anadolu'ya gelmeden önce ekmeği "etmek/ötmek" gibi kelimelerle karşıladıklarını Dîvânü Lügati't-Türk ve Kutadgu Bilig'den (bk. Atalay, 2006:102; Clauson, 1972: 60; Kobya, 2013: 826) ve yine Uygurların da "äkmäk" şekliyle kullandıklarını dönem vesikalarından öğrenmekteyiz (Caferoğlu, 1993: 47; Ögel, 2000: 35-53). Yine edebî metinlerden hareketle zaman içerisinde "ekmek" kelimesinin etrafında yan ve mecaz anlamların oluştuğu, deyimlerin ve kalıplaşmış ifadelerin ortaya çıktığı da bilinmektedir (bk. Zülfikar, 2012). Bu sebeple kelimenin edebî metinlerdeki kullanım biçimlerine bakmak, kelime etrafında oluşan bu anlam dünyasının tespit edilebilmesi için yararlı olacaktır.

\footnotetext{
2 “Din direği ilk pîrleri Hz. Âdem'dir ki âyet, 'Şu ağaca yaklaşmayın. Yoksa ikiniz de (nefsine) zulmedenlerden olursunuz.' [Bakara, 35] diye buğday ağacından yeme diye Allah Âdem'e emreder. İnsan unutkan olduğundan Hakk'ın emrini unutup yeryüzüne inince yine Hakk emri ile buğdayı Cebrail getirip bir diktikde buğday kaynatmıştır. Âdem Peygamber'in yiyerek açlığının giderdiği ilk yiyecek buğday çorbasıdır. Hâlen bir kimse evine bir adam davet etse "Baba aşı çorbası yiyelim" der. Muhallebi aşı şekerli pâlûde yiyelim demez. Daha sonra Cebrail'in öğretmesiyle Hz. Âdem Peygamber buğdayı un edip hamur edip sonra ekmek edip sıcak iken yiyip açlığını giderdi. Bundan dolayı taze sıcak ekmek taze can verir. Bu yüzden ekmekçilerin pîri $\mathrm{Hz}$. Âdem'dir." (Kahraman ve Dağlı, 2003: I-3/490-491)
} 


\section{Ekmeğin Gerçek/Temel Anlamlarıyla Kullanımı}

Ekmeğin edebî metinlerde öncelikle "tahıl unundan yapılmış hamurun fırında, sacda veya tandırda pişirilmesiyle yapılan yiyecek" şeklindeki temel anlamılla kullanılması söz konusudur. Bu da bizi dönem toplumlarında hangi ekmek çeşitlerinin yapıldığı, bunların nerede ve nasıl üretildikleri, şekil ve içerik özellikleri, lezzetleri, hangi yiyeceklerle birlikte tüketildikleri gibi gündelik yaşama ait bilgilere ulaştırması açısından önemlidir.

\section{Ekmek Çeşitleri}

Çalışmanın konusu her ne kadar klasik Türk edebiyatı metinleriyle sınırlandırılmış olsa da ekmeğin Türk kültür tarihi içindeki yerini belirleyebilmek için meseleye daha geniş bir ölçekte bakmak yerinde olacaktır. Bu çerçevede Türklerin yeme kültürüne ve özellikle ekmeğe ait geniş bilgilerin yer aldığg ilk kaynaklar arasında Dîvânü Lügati't-Türk ve Kutadgu Bilig yer alır. Reşat Genç (1982), "XI. Yüzyılda Türk Mutfağı” adlı çalışmasında söz konusu kaynaklara dayanarak şu bilgileri aktarmaktadır: Türkler, çok çeşitli ekmekler yapıyorlardı. Yapılan ekmeklerin başında da "yufka" geliyordu ki günümüz Anadolu'sunda da durum aynıdır. Ayrıca "katmer" yapımı da biliniyordu. "Sinçu" adı verilen bir çeşit ekmek ise, yapılışı itibariyle bugünün pidesini andırmaktadır. Ayrıca onların "kevşem etmek" adını verdikleri ve Kaşgarlı'nın da "mayalı, güzel, iyi pişmiş semirtici ekmek" olarak tarif ettiği ekmek, herhalde bugünkü somunların benzeri bir ekmek çeşidi olmalıdır... Yine Türkler XI. yüzyılda bugünkü şekli ve adı ile "çörek"i de biliyorlar ve çeşitli çörekler yapıyorlardı. Bu çörek çeşitleri arasında, kızgın küle gömülerek pişirilen kül çöreği çeşitleri de vardı ki bunlardan "kömeç" adı verileni günümüzde de "gömmeç" adı ile varlığını hala korumaktadır. Yine, yufka ekmekler yemeklerin yanı sıra yenildikten başka, dürüm yapılarak da yeniliyordu ki bugün de yufka ekmeği genellikle dürüm yapılarak yenilmektedir.

Evliya Çelebi de ekmekçi esnafını anlattığı bölümde, yaşadığı dönemde yaygın olarak üstü çörekotlu, susamlı hâs beyaz ekmekler, Ramazan pideleri, somunlar, lâvaşa, yufka türünden ekmekler yapıldığını (Kahraman ve Dağl1, 2003: I-2/491) kaydetmiștir.

${ }^{3}$ http://www.tdk.gov.tr/index.php?option=com gts\&arama=gts\&guid=TDK.GTS.5d7c7 47f4df437.45696965 (ET: 14.09.2019) 
Edebî metinler üzerinde yaptığımız taramalar sonucunda da Osmanlı toplumunda yufka, k/girde, tandır ekmeği, bazlamac, somun, fodla, çavdar ekmeği gibi ekmek çeşitlerinin sıklıkla tüketildiği tespit edilmiştir.

İnsanların gündelik yaşantısında önemli bir yer tutan bu ekmek çeşitleri, çeşitli şairler tarafından şiirin benzetme dünyası içerisine alınarak kullanılmıştır. Bu çerçevede aşağıda tespit edilen örnekler üzerinden ekmek çeşitlerinin edebî metinlerdeki kullanım biçimleri ve kazandıkları anlamlar incelenecektir.

\section{Ekmek:}

En temel anlamıyla günlük hayatın devamını sağlayan besin maddesi olarak ekmek kelimesiyle metinlerde karşllaşmak mümkündür. Bu anlamıyla İspanya'da esir olarak yaşamak zorunda kalan Esîrînin şiirine de yansıdığı görülür. Kendisine yabancı olan bir coğrafyada bulunan şair, başka yemeklerle ilgili olumsuz fikirlere sahipken ekmek, simit ve zeytini över. Ekmeğin, simidin ve zeytinin bol olduğu diyarda yapılan ekmeğin kar gibi beyaz ve çok lezzetli olduğunu söyler:

\section{Dahı zeytûn agaçları hezârân}

Simît ü etmegi olup firâvân

Acâib hûb u zîbâ etmegi var

Beyâzlghı şu resme sanki ak kar [Esîrî, Sergüzeştnâme, 1227-1228 (Kutlar Oğuz vd. 2018: 160)]

\section{Yufka:}

Yufka, hamurun oklava veya merdane yardımıyla ince yapraklar şeklinde açlarak sacda pişirilmesiyle yapılan bir ekmek çeşididir. Günümüzde aynı şekilde yapılmaya devam eden yufka, Basîrînin aşağıdaki beytinde yapraklar hâlindeki ince hamuru dolayısıyla bir benzetme unsuru olarak kullanılmıştır. Şairin tasvirinde sofra deftere, üzerindeki yufkalar da bu defterin varaklarına/yapraklarına, salma (bk. Yerasimos 2002: 64-65) ve mahiçenin içindeki hamur parçaları da sıfıra ve elife benzetilmiştir. Şairin yaptığ bu benzetmelerle sofra tam bir hesap defterine dönmüştür:

Salmanun her yapragı sıfr oldı mâhîçe elif Yufka evrâk-ı hisâb u sofra defterdür bana [Basîrî, XLII/3 (Kartal, 2000: 94; Başpınar, 2011: 570)] 


\section{K/Girde:}

Şiirlerde söz konusu edilen bir başka ekmek çeşidi de k/girdedir ${ }^{4}$ Şiirlerdeki tariflerden girdenin yufkaya benzer şekilde, hamurun oklava veya merdane yardımıyla yuvarlak ve ince bir şekilde açılması suretiyle yapıldığı anlaşılmaktadır. Tırsî, şiirinde k/girdecinin merdane yardımıyla yufka açtı̆̆ 1 söylemektedir:

\section{Merd ise eğer girdeci merdâne gerekdür}

\section{Yufka aça bir bir}

Pür-ma'rifetüm dirse benüm de nelerüm var

Söyletme beni var

[Tirsî, $\quad$ Mst.III/3

(Yılmaz, 2017: 217)]

Neşâtî de aşağıdaki beytinde ay ve güneşi girdeye benzetmiştir. Şair, kurguladığı hayâlde gökyüzünü kızgın bir ekmek tavası, şafağı ateş, yıldızları da ateşin kıvılcımları olarak tasavvur etmiştir. Güneş ve ay, birbiri ardınca dönüşümlü olarak gökyüzünde doğup batmalarıyla, gece gündüz durmaksızın çalışan bir fırında pişen girdelere benzetilmiştir.

Girde-i mihr ü mehe bu tâbe-i pür-tâbda

Nârdur gûyâ şafak encümdür ahker rûz uşeb [Neşâtî Dîvânı, K2/10 (Kaplan, 1996: 6)]

Nâdirî, aşağıdaki beytinde aslında günlük hayatta çok sıradan olan bir olaya temas eder. Bu olay, yanmış olan ekmeğe kimsenin itibar etmemesi, onu yemek istememesidir. Beyitte ayın etrafındaki hâlenin gümüş bir tabak içinde girde ekmeği getirdiği ancak yer yer yanmış olduğu için kimsenin bu ekmeğe rağbet etmediği belirtilmiştir ${ }^{5}$. Bu benzetmede ay ile girde arasında şekil ve renk bakımından bir ilgi kurulduğu görülmektedir. Ay öncelikle yuvarlak olması dolayısıyla şekil bakımından girdeye benzetilmiştir. Yine -

4 Sacda pişirilen yağlı ince ekmek (Türkiye Türkçesi Ağızları Sözlüğü) http://www.tdk.gov.tr/index.php?option=com bts\&arama=kelime\&guid=TDK.GTS. $\underline{5 \mathrm{~d} 7 \mathrm{cf} 8 \mathrm{~d} 34 \mathrm{fb} 1 \mathrm{c} 0.71218478}$

Genellikle mısır unuyla yapılan bir tür pide (Güncel Türkçe Sözlük), Mayasız hamurdan yapılan içi haşhaşlı ya da peynirli pide (Türkiye Türkçesi Ağızları Sözlüğü), Tandır ekmeği, pide (Tarama Sözlüğ̈̈)

http://www.tdk.gov.tr/index.php?option=com bts\&arama=kelime\&guid=TDK.GTS.5d 7cf8ca4b3ba2.27412957 (14.07.2018)

${ }^{5}$ Evliya Çelebi, Seyahatnâme' de yanık ekmeğin ilgi görmemesiyle ilgili şu bilgiyi paylaşır: “...'Bütün yanmış şeyler haramdır.' demişlerdir. Hakka ki yanık ekmek de haramdır... (bk. Kahraman ve Dağli, 2003: I-2: 511). 
güneşin ıșı̆ı̆ını yansıtması sebebiyle- temelde beyaz olan ay, üzerindeki siyah bölgeler sebebiyle de renk bakımından girdeye benzetilmiştir. $\mathrm{Bu}$ benzetmede yer alan ay üzerindeki siyahlıklar, ay tutulmasını da hatırlatmaktadır. Zira tutulma sırasında ay yüzeyi dünyadan yer yer karanlık olarak gözlenmektedir:

Getürdi hâle bir sîmîn tabakla girde-i nân

Velîkin câ-be-câ yanmış diyü meyl itmedi aslâ

[Nâdirî Dîvânı, K1/52 (Külekçi, 1985:106)]

\section{Tandır Ekmeği:}

Arapçadan Türkçeye geçmiş olan tandır kelimesinin aslı "tennûr"dur. Yere çukur kazılmak suretiyle yapılan bir firındır ${ }^{6}$. İçerisinde çeşitli yemekler yapıldığı gibi ismini bu firından alan ekmekler de pişirilir. Tâcîzâde Cafer Çelebi, bahar mevsimini tasvir ettiği aşağıdaki bentte güllerin açılmasıyla tandır ekmeğinin yapılması arasında bir ilişki kurmuştur. Gülün fırıncıya, güneşin tandır ateşine, goncanın da fırına benzetildiği bu ilişkide her sabah güneşin dünyayı 1sıtmasıyla goncaların açılarak gülün ortaya çıkması, sabahleyin tandırdan taze ekmek çıkmasına teşbih edilmiştir:

Nev-cevân olmış yine pîr-i kühen-sâl-i cihân

Sebzeler bitmiş riyâz-ı cennet olmış bôstân

Berre-yi gerdûna bulup âteş-i mihr iktirân

Hân-ı bezminçün kuzı biryânın eyler âsumân

Her seher gonca tennûrunda çıkarır tâze nân

Benzer olmuş matbahında kemterîn habbâz gül [Tâcîzâde Cafer Çelebi Dîvâni, 32/23) Erünsal, 2018: 362]

Yukarıdaki benzetme ilgisinin kurulmasında güllerin şekil ve renk bakımından tandır ekmeğine benzemesi etkili olmuştur. İspanya'da bir kalede esir olarak tutulan 16. yüzyıl şairi Esîrî de İspanyol ekmeklerini rengi dolayısıyla "beyaz güle" benzetmiştir:

Üzümi encîri gâyetde boldur

Sanasin etmegi bir ak güldür [Esîrî, Sergüzeștnâme, 689 (Kutlar Oğuz vd. 2018: 99)]

${ }^{6}$ http://www.tdk.gov.tr/index.php?option=com gts\&kelime=TANDIR $($ ET: 29.09.2019) 


\section{Bazlama}

Sacda pişirilen yuvarlak bir ekmek çeşidi olan bazlama Sultan Veled'in oldukça ünlü- bir şiirinde ${ }^{7}$ de zikredilmektedir. Şair söz konusu beyitte Allah'tan bir çanak yemeğin yanında iki üç bazlama istemektedir:

Uçmak aşından dilervem bir çanak

Nûr hamîrinden iki üç bazlamaç [Sultan Veled (Kılıç, 2003: 3)]

Taşlıcalı Yahya da 1533-1535 yılları arasında yapılan sefer sırasında yaşanan açlık ve kıtlığın konu edildiği şiirinden alınan aşağıdaki beyitte açlık askerinin karşısında siper olarak kullanmak üzere bir bazlamaya ihtiyaç duyduğunu belirtmektedir. Bu söyleyişte bazlama, şekil itibarıyla kalkana, açlık da ok ve yayla saldıran askere benzetilmiştir.

Açlik çerisi tîr ü kemân ile yüridi

Bir bazlamac olaydı iderdüm ana siper [Yahyâ Dîvânı, K25/10 (Çavuşoğlu, 1977:106)]

Yukarıdaki beyitlerde yer alan söyleyişlerden bazlamanın çabuk yapılan ve kolay erişilebilen bir ekmek çeşidi olduğu anlaşılmaktadır.

\section{Somun}

Şiirlerde görülen bir başka ekmek çeşidi de somundur. Somun, sözlüklerde yuvarlak ve şişkin olarak tarif edilen ekmek çeşididir. Kanunî Sultan Süleyman 1556 yılında ordusu ile Edirne'de kışlayınca artan tüketimden dolayı şehirde ekmek kıtllğı baş göstermiştir. Garâmî de "somun" redifli şiirinde bu kıtlığı dile getirerek somuna olan hasretini mizahi bir dille anlatmıştır:

Çok zamândur ikimüz bir sofrada konuşmaduk

Cenge girüp birbirimüzle el sunuşmaduk

Sofra sahrâsında esb-i ekle binüp koşmaduk

Karvaşalum gel berü meydâna aslanum somun

Msm.2/1 (Başpınar, 2013: 98)]

[Garâmî Dîvânı,

\footnotetext{
${ }^{7}$ Aslında tasavvufi manada anlamlandırılması daha uygun olan şiirin bu tür bir yorumu için bk. Kılıç, 2003.

${ }^{8}$ https://sozluk.gov.tr/(ET: 29.09.2019)
} 


\section{Çörek}

Türk mutfak kültüründe yer alan ekmek çeşitlerinden bir diğeri de çörektir. Tüketilen diğer ekmeklere göre daha yağlı olan çörek, zaman zaman şeker ve yumurta ilave edilerek de tatlandırılır'. Zâtînnin aşağıdaki beytinde çöreğin pişirilme süreci söz konusu edilmiştir. Beyitteki ifadelere göre şairin bahsettiği çöreğin kızgın külün içine gömülerek pişirildiği anlaşılmaktadır. $\mathrm{Bu}$ süreç şiirin benzetme dünyası içerisinde âşı̆̆ın bağrından yaralar çıması ile ilişkilendirilmiştir. Bu ilişki içerisinde âşı̆̆ın sinesi, küle; yaralar da çöreğe benzetilmiştir. Nasıl ki küle gömülen ekmek piştiği zaman külden çıkartılırsa âşık da -aşk yolunda pişmiş olduğunu gösteren- sinesindeki ateşli yaralarını saklamaya gerek görmemektedir:

Dâg-ı pür-sûzumı hâkister-i sînemde begüm

Ne içün saklayayın çig mi sanursuz çöregüm [Zâtî Dîvânı, G954/1 (Tarlan, 1970: II/458)]

Gelibolulu Mustafa Âlî, kaleme aldığı Sûrnâme'sinde dügüne katılan İran elçilerine ikram edilen yemeklerin yanında çörek bulunduğu bilgisini vermektedir. Söz konusu beyitte çörekler, şekilleri ve renkleri dolaysıyla ayın ve güneşin etrafındaki halelere benzetilmiştir:

Her şâm u seher gönderilüp nice yemekler

Hem kurs-ı meh ü mihre bedel nice çörekler [Âlî, Câmi'u'l-Buhûr

Der Mecâlis-i Sûr, 2264 (Öztekin, 1996: 248)]

Taradığımız metinlerde yukarıdakilerden başka fodla ve çavdar ekmeğinin de yer aldığı görülmüştür. Bunlarla ilgili kullanımlara, aşağıda birlikte anıldıkları çorbalarla birlikte yer verilecektir ${ }^{10}$.

\footnotetext{
${ }^{9}$ http://www.tdk.gov.tr/index.php?option=com bts\&view=bts\&kategoril=veritbn\&keli $\underline{\text { mesec }=80341}($ ET: 29.09.2019)

${ }^{10}$ Metinlerde ekmek çeşitleri dişında simit, poğaça, börek gibi hamurdan yapılan başka yiyecekler de yer almaktadır. Ancak bunlar doğrudan ekmek çeşitleri olmadığı için buraya alınmamıştır.
} 


\section{Ekmeğin Tüketimi}

\section{Ekmek ve Çorba}

Türk yemek kültüründe en az ekmek kadar vazgeçilmez olan bir diğer yiyecek türü de çorbalardır. Osmanlı mutfağı üzerine yapılmış çalışmalardaki listelerde çok sayıda çorba çeşidi bulunmaktadır. Taradığımız metinlerde ekmekle birlikte özellikle tarhana çorbasının zikredildiği görülmüştür. Tırsî, aşağıdaki beyitte sofraların vazgeçilmezi olan tarhana ile ekmeği birlikte aynı mısrada kullanmakta ve karşısındaki kişiye "tarhana benim, ekmek senin olsun" şeklinde şaka yollu bir teklifte bulunmaktadır. Şiirde yer alan başka paylaşım tekliflerinde şairin iyi olanı daima kendisi için istemesinden hareketle tarhananın ekmekten üstün tutulduğu anlaşılmaktadır:

Tarhana benüm sofradaki nân senün olsun

Kestâne benüm meclis-i yârân senün olsun [Tirsî Dîvânı, G CXLVIII/1 (Yılmaz, 2017: 157)]

Yine Tırsî, kış mevsiminin insanların gündelik yaşantısına etkisini anlattığ 1 aşağıdaki beyitte kış günlerinde sabah kahvaltıda çorba, özellikle de tarhana çorbası yemek istediğini söylemektedir. Tarhananın sarımsaklı ve yağlı ekmekle birlikte servis edilmesi de şairin istekleri arasındadır. Buradaki ifadelerden ekmeğin yapımı ve/veya tüketimi sırasında değişik gıda maddeleri ile çeşnilendirildiği anlaşılmaktadır:

Kış güni kahvaltıya şûr-bâ yiyen gelsün diyem

Sarımsaklı yağlı etmekler gerek terhânede [Tirsî Dîvânı, G CLXXXIV/7/1 (Yllmaz, 2017: 187)]

\section{Fod(u)la ve Çorba}

Tırsî bir başka beytinde de -yukarıdaki beyitlerine benzer şekilde- sabah kahvaltısı için yine bol sarımsaklı tarhana çorbası ve yanında da fodla ekmeği istemektedir. Şair, beyitte aynı zamanda tarhananın sarhoşluğun etkilerini giderdiği bilgisini/inancını da vermektedir:

Bol sarımsak ile fodla ile olursa severüm

Her sabâh def'-i humâr itmege tarhâne ile [Tırsî Dîvânı, G CLXX/4 (Yılmaz, 2017: 176)] 
Beyitte zikredilen "fodla" ekmeği, Ramazan pidesine benzer biçimde ince, fazla mayalanmış özsüz hamurdan yapılan ve kolay kopma özelliğine sahip ve daha ziyade imaretlerde, saray mutfağında, İstanbul'daki diğer bazı saraylarda ve yeniçerilere ait fırınlarda pişirilir, bir kısım görevlilere maaşları ile birlikte sepet içinde istihkakına göre tayın olarak dağıtılırdı. Bu ekmeğin pişirilip dağıtılması için resmî bir teşkilât oluşturulmuştu (bk. Kahraman ve Dağl1, 2003: I-2/491). Fodula kelimesinin nereden geldiği ve bu ekmeğin ne zamandan beri pişirilip dağıtıldığı bilinmemekle birlikte Evliya Çelebi'nin bu kelimeyi -eğer bir istinsah hatası değilse- 'oruç açılan yiyecek' anlamına gelen 'fatûre' şeklinde yazması fodla kelimesinin bununla ilgili olduğunu düşündürmektedir (Emecen, 1996: 167-168).

Yukarıdaki üç beyitte tarhana ile ekmeğe övgülerde bulunan Tırsî, aşağıdaki beyitte bu kez kahvaltı yerine tarhana ve fodla çımasından şikâyet etmektedir. Şairin isteğinin farklılaşma nedeni ise mevsim değişimidir. Zira yukarıdaki beyitlerde mevsimin kış olduğu, aşağıdaki beyitte de yaz olduğu özellikle belirtilmiştir. Günümüzde de soğuk kış sabahları için çorba özellikle de tarhana çorbası- tercih edilen bir kahvaltı seçeneği iken sıcak yaz günleri için çok uygun bulunmaz. İkinci mısradaki "hep" vurgusundan hareketle, kış mevsiminde sabahları sürekli ekmek ve tarhana çorbası yemiş olan şair, artık bu durumdan bıkmıştır. Şairin tepkisinin değişmesindeki bir diğer etken de bu bıkkınlık hâlidir:

Yaz geldi diyü sâdece kahvaltı yerine

Hep fodla-i seg-bân ile terhâne mi çıkdı [Tırsî Dîvânı, G CCV/2 (Yllmaz, 2017: 205)]

Beyitteki seg-bân kelimesi üzerinde ayrıca durulması gerekmektedir. Çünkü Fatih döneminden itibaren av köpeklerinin yiyecek ihtiyaçlarını karşılamak için de kurulmuş olan bir fodla firının varlığı bilinmektedir ${ }^{11}$.

Fodlanın toplumda rağbet gören bir ekmek çeşidi olduğunu yine döneme şahitlik eden Hevâyînnin mırralarından öğrenmekteyiz. O kadar çok taliplisi vardır ki fodla dağıtan imaretin kapısı kalabalık tarafından kapatılmış ve içeriye girmenin imkânı kalmamıştır. Öyle ki imaretin içine girilebilecek tek yer olarak bacası kalmıştır. Burada şairin, halkın yoksullara yiyecek

11 "Sarayda fodula dağıtımının resmî bir özellik kazanması muhtemelen Fâtih Sultan Mehmed zamanında oldu. Nitekim Kavânîn-i Yeniçeriyân’a göre Fâtih döneminde av köpeklerinin yiyecek ihtiyaçlarını karşılamak için bir fodula fırını kurulmuştu. "Sekban firını" da denen bu firın Ayasofya civarında bulunuyordu." (Emecen, 1996: 168) 
dağıtmak amacıyla kurulmuş olan imaret önünde toplanmasına vurgu yapması, toplumdaki yoksulluk seviyesine ilişkin bir eleştiri amacı da taşımaktadır. Ayrıca fodlanın ucuza mal edilen, kalitesi düşük bir ekmek çeşidi olduğu izlenimini de uyandırmaktadır ki bu durum, Evliya Çelebi’nin fodla ile ilgili verdiği "düşük kaliteli undan yapıldığg ancak lezzetli bir ekmek olduğu (bk. Kahraman ve Dağll, 2003: I-2/491)” şeklindeki bilgilerle de uyumludur:

Kapatmış halk imâret kapusını fodla istersen

Tolaş tam üstüne çık bacadan zenbîller sarkıt [Hevâyî Dîvânı, G10/3 (Çakır, 1998: 5)]

\section{Çavdar Ekmeği ve Çorba}

Metinlerde yer alan bir diğer ekmek çeşidi de çavdar ekmeğidir. Tirsî, uzun zamandır çavdar ekmeği ile birlikte tarhana çorbasına hasret olduğunu, artık hâcegânlar arasına katıldığ söylemektedir. Hâcegân ${ }^{12}$ zümresinin Osmanlı sosyal yapılanması içinde itibarlı bir yere sahip olmasından dolayı bahse konu olan ekmeğin özel sayılabilecek yiyecekler arasında bulunduğu izlenimi ortaya çıkmaktadır:

Hâcegân zümresine girdin ey Tirsî-fakîr

Nân-ı çavdar ile biz hasret-i terhâne idük [Tırsî Dîvânı, G CXXII/7 (Yilmaz, 2017: 135)]

\section{Ekmek ve peynir:}

Ekmek şiirlerde çorba dışında peynirle birlikte de anılmıştır. Tespit edilen beyitlerdeki kullanımlarından ekmek ve peynirin yoksulluk göstergesi olarak kabul edildiği anlaşılmaktadır. Hevâyînnin sosyal eleştiri içerikli aşağıdaki beytinde büyüklerin sofrasına bütün kuzu bulunurken düşük gelirli insanların payına peynir ekmek düşmektedir. Şairin söylemi aynı zamanda bulunulan yere ve konuma göre yiyecek tercih etmeye de vurgu yapmaktadır. Eğer bağa gidilmişse ve çalışllacaksa peynir ve ekmeğin yiyecek olarak kullanılması daha uygun iken özel zamanlar için çeşitli et yemekleri hazırlanır:

\footnotetext{
${ }^{12}$ Hâcegân, Osmanlı devlet teşkilatında yazı işlerinin başında, defterdarlık, nişancılık gibi memuriyetlerde, eminlik ve müdürlüklerde bulunanlar için kullanılan tabirdir (bk. Pakalın, 1983: I/693).
} 
Hemân bize yiyecek bâğda peynir etmektür

Bütün kuzuya mahal sofra-i kibâra düser

(Yıldırım, 2004: 47)]

[Hevâyî̀ Dîvânı, G38/2

Azmîzâde Hâletî de aşağıdaki beytinde peynir ve ekmeği yoksulluk göstergesi olarak kullanmıştır. Şairlik yeteneği ile kazanç arasında bir ilişki kuran Hâletî, şiirinde peynir ve ekmek (nân u penîr) kelimelerini kafiye/redif olarak kullanan şairin kazancının elbette düşük olacağını söylemiştir. Şairin bu söylemi, şiirin içeriği ile ilgili kabullere/beğenilere eleştiri niteliği taşımaktadır:

Ma'âş-1 şấir olur kıllet üzre elbette

Meger ki kâfiye-i şi ri ola nân u penîr

[Hâletî Dîvânı, K17/18 (Kaya, 2017:117)]

\section{Ekmeğin Simgesel Anlamları}

Türkçede ekmeğe gerçek anlamının dışında mecazî anlamlar yüklendiği ve ekmeğin bu anlamlarıly sosyal ilişkilerin simgesel bir göstereni olarak kullanıldığı da görülür. Aşağıda edebî metinler üzerine yaptı̆̆ımız taramalarda tespit ettiğimiz, ekmeğin kazandığı simgesel anlamlara ilişkin kullanımlar değerlendirilecektir.

\section{Rizık Allah'tandır}

Ekmeğin Türkçede kazandığı anlamlardan biri, "rızık" kelimesinin karşıllğı olarak yiyecek ve içecek bütün besin maddeleridir ${ }^{13}$. Kelime bu anlamıyla toplumsal ilişkilerde anlaşmaların, anlaşmazlıkların, çatışmaların yaşandığı bir alana karşlık gelmektedir. Bu sebeple de kelime, pek çok şiirde söz konusu anlamıyla işlenmiştir.

Bütün canlıların rızkını veren ve garanti altına almış olan ancak Allah'tır. Durum böyle iken insanoğlu zaman zaman bu hakikati unutarak farklı arayışlara girer ve başka insanlardan ekmek umar. Hâlbuki eğer rızık taksimi insanların eline bırakılmış olsaydı hırs ve kıskançlıkla kendilerinden başka kimseye yiyecek tek bir lokma dahi vermezlerdi. Nâbî, toplumun aksayan yönlerini dile getirdiği sosyal eleştiri içerikli bir şiirinde bu konuya değinmiştir. Söz konusu şiirde, sadece kendini beğenip sadece kendini önemseyen dönem insanının mal, mülk biriktirme sevdasına düşmesi, makam, mevki elde etme hırsına kapılması, şöhret peşinde koşması

${ }^{13}$ Burada ekmeğin aynı zamanda kendi anlamı dışında "yenilen her şey” yani "yemek" anlamında kullanıldığını da vurgulamak gerekir. "Bu anlamda dilde ekmeğini eline almak, ekmeğinden olmak deyimlerini buluyoruz.” (bk. Zülfikar, 2012: 14) 
neticesinde toplumsal değerlerin nasıl aşındığı anlatılmıştır. Bu çerçevede kaybedilen değerlerin en önemli göstergelerinden biri de ekmektir. Hırsa kapılan insanoğlu o hâle gelmiştir ki çıkarı olmasa başkalarına "ekmek bile vermez". Burada ekmek sadece yiyecek maddesi olmanın yanında daha geniş çerçevede "iş, kazanç, rütbe, makam, mevki" anlamlarını da çağrıştıracak şekilde kullanılmıştır:

Virmezdi kimse kimseye nân minnet olmasa

Bir maslahat görülmez idi rüşvet olmasa [Nâbî Dîvânı, G757/1 (Bilkan,1997: II/1028)]

Nâbî başka bir beytinde böylesine bir hırsa kapılanları "alçak cahiller (câhili dûn)" olarak tanımlar. Çünkü rızkı veren ancak "Rezzâk" olan Allah’tır. Allah'ın takdir ettiği rızkı engellemeye de kimsenin gücü yetmez. Ancak bu gerçeği bilmeyen yahut gözünü hırs bürüdüğü için unutan insanlar kıskançlıkla başkalarının "ekmeğine mani olmaya" çalışırlar:

Men 'i nân-pâremüze kûş̧iş iden câhil-i dûn

Degül a men 'ine kâdir kerem-i Rezzâkun [Nâbî Dîvânı, G441/6 (Bilkan,1997: II/795)]

Sultan Veled de aşağıdaki beytinde rızkı verenin Allah olduğunu açıkça belirtmiştir. Tasavvufi düzlemde yorumlanması daha uygun olduğunu daha önce de belirttiğimiz şiirde ${ }^{14}$-en azından lafzen- karnının aç olduğunu belirten şair, Tanrı'dan rahmetiyle kendisine bir kapı açmasını istemektedir:

Karnum açdur karnum açdur karnum aç

Rahmet itgil Tanrı bana kapu aç [Sultan Veled (Kıllı̧, 2003: 3)]

\section{Başkasının Ekmeğine El Uzatmama}

İnsan, Allah'a sığınıp yalnız ondan isterse dilediği her şeye sahip olabilecekken başkasına el açmasına, başkasının ekmeğine el uzatmasına gerek yoktur. Zira bu dünyada kimse rızkını başka birine vermez. Bu yüzden başka insanlara minnet etmeye gerek yoktur:

Hak murâdın vericidür kişinün

Minneti Hakka durur her kişinün

Eyle minnet ol Hudâya dâ'imâ

Nânına el sunma gel her kişinün

\footnotetext{
${ }^{14}$ Şiirin tasavvufi yorumu için bk. Kılıç, 2003.
} 


\section{Minnet ile ger yesen sükker dahı Agu olur içine ol kişinün}

\section{Minnet olmasun cihânda kimseye}

Kimse vermez rızkını hîç kişinün [Esîrî, Dîvân-ı Firâk-ı Esîrî, G73/14 (Kutlar Oğuz vd. 2018: 389-390)]

Esîrî yukarıdaki üçüncü beytinde bu konuda başka bir noktaya daha temas etmiştir. İnsan, tabiatı gereği yaptığı iyiliği “başa kakma” ve iyiliğine karşılık bekleme eğilimdedir. Bu sebeple başka bir kişiye minnet edilerek yenilen yemek şeker dahi olsa yiyen kişi için zehir olur. Yine Esîrî aynı noktaya vurgu yaptığı başka bir beytinde de bu tür kişileri daha ayrıntılı bir şekilde tasvir etmektedir. Buna göre nâdân (anlayışsız ve cahil) kişilere minnet etmemek ve namert insanların lokmasını yememek gerekir:

Sunma nâ-merd lokmasina el sakın

Etme minnet cihânda nâ-dâna [Esîrî,, Dîvân-ı Firâk-ı Esîrî, K12/30 (Kutlar Oğuz vd. 2018: 460)]

Zâtî de tam bu sebeple, isteklerini sadece Allah'tan dileyen ve kendi payına düşene rıza gösteren kişilerin cennet nimetlerine kavuşmasının mümkün olacağını belirtmektedir. Buradaki "ni'met-i cennet" söylemi, bu dünyadaki külfetlerin ödülünün ahirette alınacağı inancını belirtmenin yanında Allah'ın takdir ettiği nimetlere kanaat eden kişiler için -kimseye bir minnet borcu olmadığından- bu nimetlerin az da olsa cennet nimetleri gibi lezzetli geleceğini de ifade etmektedir:

Cihânda ekmegüni başka yime ey Zâtî

Ki sana ni'met-i cennet nasîb ide Rezzâk [Zâtî̀ Dîvânı, G657/7 (Tarlan, 1970: II/161)]

\section{Aza Kanaat Etme / Çoğa Tamah Etmeme}

İnsanın kendi payına düşen nimetlerle yetinmeyip aç gözlülükle hep daha fazlasını istemesi onu mutsuz ve huzursuz edecektir. Zira beslenmenin en temel amacı, hayatta kalmak ve yaşamını sürdürmek için vücudun ihtiyaç duyduğu besin maddelerini almaktır. Yeme eyleminin sadece beslenme yönüyle öne çıtı̆̆ bu aşamada kişinin asgari düzeyde besleyiciliği olan besin maddeleriyle "karnını doyurması" yeterlidir. Bu aşamada ihtiyaç duyulan ve en kolay ulaşılabilen yiyecek ekmektir. Yine karnını doyurabileceği kuru ekmeği temin edebilecek kadar bir gelire sahip olması da yeterlidir. Edebî eserlerde ekmeğin yoksulluğa karşılık gelen tüketimi de 
konu edilmiştir. Bağdatlı Rûhî, meselenin bu yönüne değindiği aşağıdaki beyitte okuyucusuna "Seni ekmek doyurmaz mı? Doymak için illa et mi yemen lazım?" diye sorduktan sonra "Alçakların artığı olan o lokma zehir olsun!” şeklinde uyarıda bulunur. Sosyal eleştiri amacı da taşıyan bu beyit, "Çoğa tamah edip onurunu kaybetmektense elindeki aza kanaat etmek daha iyidir.” mesajıyla karşımıza çıkar:

\section{Et lokması lâzım mı toyurmaz mı seni nân}

Zehr olsun o lokma k'ola pes-mânde-i dûnân

Dîvânı (Ak, 2001: 192)]

[Bağdatlı Rûhî

Yaşamak için "kuru bir ekmek parçası" yeterliyken bu fani dünyada başka insanlardan rızık ummaya da başkasının rızkına mani olmaya çalışmaya da gerek yoktur. Zira insanoğlu bu dünyada çalışıp çabalayıp ne kadar çok mal biriktirse de ölünce sahip olduğu her şeyi geride bırakacaktır. Hz. Peygamber'in de belirttiği üzere ${ }^{15}$, kendisi gibi makam ve mevkisi, malı ve mülkü de fani olan bu dünyada insanoğlunun gerçekten sahip olabileceği ender şeylerden biri yedikleridir. Bu sebeple kişinin tükettiği her bir lokmanın helal olması temel esastır.

\section{Helal Lokma Yemek}

Türkçede ekmeğin kazandığı önemli anlamlardan biri de -yukarıdaki beyitlerde de görüldüğü üzere- geçim vasıtası, kazanç anlamında kullanılmasıdır ${ }^{16}$. Kazanç söz konusu olduğunda da insan için en önemli nokta, geçimini helal yollardan sağlamasıdır. Bunun için de insanın geçimini, inancın, toplumsal kabullerin ve hukuki normların onayladığ 1

${ }^{15}$ Söz konusu Hadîs-i Şerîf şu şekildedir: "Âdemoğlunun şu üç şey dişında (temel) hakkı yoktur. İkamet edeceği bir ev, avretini örteceği bir elbise, katıksız bir ekmek ve su." (Tirmizî, Zühd 30, hadis no: 2342). Aynı Hadîs-i Şerîf şu şekilde de kaydedilmiştir: Abdullah İbnu'ş-Şihhîr (r.a.) anlatıyor: "Rasûlullah (s.a.s.) El-hâkümü’t-tekâsür sûresini okurken yanına geldim. Bana: “İnsanoğlu 'Malım, malım!' der. Hâlbuki âdemoğlunun yiyip tükettiği, giyip eskittiği ve sağlı̆̆ında tasadduk edip gönderdiğinden başka kendisinin olan neyi var? (Gerisini ölümle terkeder ve insanlara bırakır.)" (Müslim, Zühd 3, 4, hadis no: 2958; Nesâî, Vesâya 1 hadis no: 6, 238; Tirmizî, Tefsîru Tekâsür, hadis no: 3351) (bk. Canan, 1988: II/45).

16 "Bu anlamda dilimizde ekmek kavgası, ekmek parası, birini ekmeğinden etmek, ekmeğini elinden almak, ekmeğinden olmak, ekmeğine göz koymak veya göz dikmek, ekmeğine mani olmak veya engel olmak, ekmeğini tepmek veya ekmeğini ayağıyla tepmek, ekmeğini taştan çıkarmak gibi deyimler bulunmaktadır. Görüldüğü gibi mecaz anlamda ekmek kelimesi en geniş bu anlamda kullanılmıştır."(bk. Zülfikar, 2012: 13) 
işlerden sağlaması esastır. Yani sadece paranın kazanılması değil, meşru yollardan kazanılmış olması da önemlidir. Bosnalı Sâbit, ekmek kelimesini "geçim vasıtası" anlamıyla kullandığı aşağıdaki beyitte, şairliğin ekmek (parası kazanmak) için kârlı bir iş olduğunu söylemektedir. Beyitteki "dişün var ise" ifadesi üzerinden şairin şiir bilgisi, hayal gücü gibi bazı özelliklere sahip olması gerektiğine vurgu yapmaktadır. Sâbit, böyle bir yeteneğe sahip olan şairin mermerin has unundan yapılmış ekmeğe minnet etmeyeceğini belirtir:

Dakîk-i hâss-ı mermer nânına minnet mi var Sâbit

Dişün var ise şâirlik gibi etmekli kâr olmaz [Sâbit Dîvânı, G133/9 (Karacan, 1991:417)]

Sâbit'in yukarıdaki beyitte yer alan "mermer unundan yapılmıs ekmek" vurgusu, "ekmeğini taştan çıkarmak" deyimine bir gönderme içermektedir. Toplumsal kabullerde "ekmek parası kazanmak" uğruna yapılan, inancın, toplumun ve yasaların onayladığı her iş meşru iken "alın teri" söylemi üzerinden fiziksel güce dayanan işlerin özellikle vurgulandı̆̆ 1 dikkati çekmektedir.

\section{Ekmeğini Taştan Çıkarma:}

Sâbit'in yukarıdaki beyti dolayısıyla bahsedilen "ekmeğini taştan çıarmak" deyimi, "geçimini sağlamakta çok becerikli olmak, en zor koşullarda bile kazancını sağlamak" anlamlarına gelmektedir ${ }^{17}$. Tırsî aşağıdaki beyitte kaldırım mumcusunun ekmeğini taştan çıkardığını belirtmiştir. Tam olarak neye karşılık geldiğini tespit edemediğimiz "kaldırım mumcusu" ifadesi, sokakta mum satan mumcu esnafinı yahut sokak aydınlatmasında kullanılan mumları yakmakla görevli kişiyi karşılıyor olabileceği gibi, günümüzdeki "kaldırım mühendisi" ifadesi gibi "işsiz güçsüz sokaklarda dolaşan kimse ${ }^{18 "}$ anlamına da geliyor olabilir. Hangi anlama gelirse gelsin şairin ifadeyi tevriyeli kullanarak hem deyimin yukarıda belirtilen anlamını hem de bahsettiği işi yapan kişinin işini kaldırım üzerinde icra ediyor olmasını vurguladığı anlaşılmaktadır:

Kaldırım mûmcısı taşdan çıkarur etmegini

Kaya başı dă̆ıdur halka huşûnet bâkî

CC/4 (Yllmaz, 2017: 201)]

[Tirsî̀ Dîvânı, G

\footnotetext{
${ }^{17}$ Anlam için bk. https://sozluk.gov.tr/?kelime=ekmeğini\%20taștan\%20çıkarmak (ET: 14.09.2019)

${ }^{18}$ Anlam için bk. https://sozluk.gov.tr/?kelime=kaldırım\%20mühendisi (ET: 15.09.2019)
} 
İkinci mısradaki "kaya baş" tabirinin, "çobanların dağlarda dolaşanların söyledikleri türküleri ve mana itibarıla basit, lisan cihetiyle iptidai ve kaba olan şiirleri” karşılamasından (bk. Pakalın, 1983: II/219) hareketle beyitte söz konusu edilen kişinin sokaklarda yahut kaldırımlarda dolaşırken veya mesleğini icra ederken şiir okuduğu ya da türkü söylediği anlaşılmaktadır. Yine mısradaki "huşunet bâkî" ifadesi, Tırsînnin okunan şiirleri, icra edilen sanat1, kaba ve sert bulduğunu göstermektedir. Beyte bu zaviyeden bakılırsa "Sanat değeri taşımayan eserler icra eden sanatçı ekmeğini taştan çıarmak zorunda kalır." şeklinde bir mana ortaya çıkar ki bu söylem, Sâbit'in yetenekli bir sanatkâr için şairliğin iyi bir gelir kapısı olduğunu söylediği yukarıdaki beytiyle koşut bir anlam ifade eder.

\section{Kuru Ekmek}

Ekmek en temel besin maddesi olarak kabul edildiği için kimi zaman sadece açlı̆̆ı giderme vasıtası olarak görülmüştür. Bu bağlamda yanında herhangi bir şey olmadan yenilen ekmek anlamında kullanılan "kuru ekmek" yani "katıksız ekmek" ${ }^{19 "}$ ekonomik açıdan zayıf olma durumunu ifade eder. "Kuru ekmek" tabiri yoksulluğa işaret ettiği gibi aslında en temel besin maddesi olarak ekmeğin varsayıldığının da bir kanıtı olarak alınabilir. Malum olduğu üzere en yaygın ve en kolay şekilde ulaşılabilen ekmeği bulamayan bir kişinin başka şeylere sahip olması mümkün değildir. Tırsî̀nin aşağıdaki beytinde muhtemelen demircilikle uğraşan ve kuru ekmekle beslenerek mesleğini icra eden bir kişi söz konusu edilmiştir. Ekmeğini taştan çıkarmak deyiminde olduğu gibi burada da meslek üzerinden hayatını zor yoldan kazanma anlamının vurgulandığı görülmektedir. Orucunu kuru ekmekle tutan bu çingene, fakirliğin acısını çıkarmak istercesine elindeki çekici olanca acı kuvvetiyle örse vurmaktadır. Redif olarak kullanılan "leziz" kelimesinin delaletiyle bu kişinin kuru ekmekle karnını doyurmaktan da yaptığı işten de mutlu olduğu anlaşılmaktadır. $\mathrm{Bu}$ hâliyle "aza kanaat edip çoğa tamah etmeme" düsturunun örneği durumundadır:

Kurı etmekle tutar rûzeyi çingâne lezîz

Acı kuvvetle urur tîşeyi sindâna lezîz [Tirsî Dîvânı, G XLII/1 (Yılmaz, 2017: 70)]

${ }^{19}$ Anlam için bk. https://sozluk.gov.tr/?kelime=kuru\%20ekmek (ET: 14.09.2019) 


\section{Cömertlik/Başkalarına İkramda Bulunmak}

İlginç bir şekilde ekmek aynı zamanda hem fakirliğin hem de zenginliğin alameti/göstereni olarak kabul edilmiştir. Kutadgu Bilig'de "başkalarına ikramda bulunmak için ekmeği ve tuzu evde bol tut ögüdü” yer almaktadır.

Tuz etmekni kin tut kişike yitür

Kişi aybı körse sen açma yitür ${ }^{20}$ [Kutadgu Bilig, 1328 (Şen, 2003: 19)]

Yine Yusuf Has Hâcib, yaşamak ve iyi bir şöhrete sahip olmak isteyen kişilere, insanlara ekmek ve tuz yedirmesi tavsiyesinde bulunmuştur:

Kü çaw at tilese tuz etmek yitür

Tiriglik tilese anı ok yetür ${ }^{21}$

[Kutadgu Bilig, 2320 (Şen, 2003: 19)]

Kutadgu Bilig'de geçen bu iki yerde de yemek yedirmek ve yemek yedirirken cömert olmak üzerinde durulmuştur. Beyitlerdeki söyleyişlerden ekmek ve tuz gibi her zaman herkesin evinde bulunan gida maddeleriyle aslinda daha geniş anlamda yenilecek her şeyin/yemeğin kastedildiği anlaşılmaktadır. Ayrıca söz konusu kelimelerle -bu çalışmada da değinildiği üzere- "tuzekmek hatırı" diye tabir edilen, birlikte yemek yiyen kişilerin birbirlerine besledikleri vefa duyguları da vurgulanmıştır.

Bağdatlı Rûhînnin letâif türündeki bir şiirinden alınmış olan aşağıdaki beytinde Çeşnici Sinan'ın sofrasının daima ekmekle dolu olduğunu belirtmiştir. Sofranın ekmekle dolu olması aynı zamanda ikram etmeyi sevme, cömert olma gibi anlamları da çağrıştırmaktır:

Dâimâ sofrası nân ile Sinân'un tolıdur

Çâş̧nigîr olan ol münkir-i dünân eyüdür [Bağdatlı Rûhî Dîvânı (Ak, 2001: I/164)]

Gelibolulu Mustafa Âlî, Sultan Murat için yazdığı kasidesinde onun cömertliğini ifade etmek için bir sofra tasviri kurgulamıştır. Hükümdarın

\footnotetext{
20 "Tuzu ekmeği bol tut, başkalarına ikram et; bir kimsenin ayıbını görürsen, açma, üstünü ört.” (Şen, 2003: 19)

21 "Adının namlı ve şöhretli olmasını dilersen, başkalarına tuz ve ekmek yedir; yaşamak dilersen yine aynı şeyi yap ” (Şen, 2003: 19)
} 
yıldızlarla dolu gökyüzünde kurulmuş olan cömertlik sofrasında güneş, kâseye; felek, çöreğe; gezegenler, çöreğin üzerindeki bademlere; yeni ay evresindeki ay da bir parça ekmeğe benzetilmiştir. Bu sofra tasvirinde ekmeğin ve çöreğin zikredilmiş olması, ekmeğin yukarıdan beri anlatılan simgesel anlamlarıla ilgili olmalıdır:

Kurs-ı bezmündür felek bâdâmıdur seyyareler

Süfre-i cûdunda gîyâ mâh-ı nev bir pâre nân K35/6 (Aksoyak, 2018: 168)]

[Âlî̀ Dîvânl,

\section{Kutsallık/Ekmeğin Öpülmesi}

Yukarıda vurgulandığı üzere ekmek, en temel besin maddesi olması hasebiyle, "ölmeyecek kadar yeme" şartını üstlenmiştir. Hayatta kalmak için yenilen şey, gerçekte kişiye, coğrafyaya, iklime vb. göre değişse de bütün sofraların ve sofralardaki bütün yemeklerin vazgeçilmezi olması dolayısıyla ekmek, insanı ölümden kurtaran yiyecek olarak görülmüştür. Beslenmeyle yaşamın, açlıkla ölümün eşdeğer hâle geldiği sınırda, hayatın/yaşama hakkının kutsal olmasının etkisiyle yaşamın devamını sağlayan ekmeğe de kutsiyet atfedilmiştir. Bundan başka ekmeğin diğer bütün besinleri ve medâr-1 maisşet için çalışmayı da temsil ettiği görülmektedir. Bütün bu alanlarda yaşamın sürdürülmesinin asgari şartlarının alemi/sembolü de yine ekmek olmuştur. Bu kabullerin oluşmasında İslam düşüncesinin de etkisi olmuştur. Öncelikle Yunus Emre'nin dilinde ifadesini bulmuş olan yaratılan her şeyde yaratanı görme ve bu yüzden yaratılmışlara sevgi besleyip hürmet gösterme anlayışı, bütün yaratılmışlar gibi "nimet"leri de hürmet edilmesi gereken bir makama konumlandırmıştır. Esasen "rızık" ile "kul" arasındaki ilişki, Kur'ân-ı Kerîm'deki "Yiyiniz, içiniz; fakat israf etmeyiniz! Çünkü Allah, israf edenleri sevmez. (A'râf 7/31)" ayetiyle belirlenmiştir. Bu ayetteki uyarı, bizzat yiyeceğin kendisini kutsadığı gibi, ölçülü beslenerek sağlıklı yaşamaya ve besin kaynaklarının bütün canlılar arasında paylaşılmasına da vurgu yapmaktadır.

Ekmeğe yüklenen bu kutsallığın izlerini, ekmek etrafında oluşan söylemler ya da ritüeller üzerinden gözlemlemek mümkündür. Sofrada ekmekle çatal, bıçak vb. temizlemenin, ekmeğin üzerine tuzluk vb. koymanın hoş karşılanmaması bu çerçevede değerlendirilebilecek inanışlardandır. Bir başka ritüel de ekmeğin öpülüp başa konmasıdır. Bu noktada ekmekten başka sadece Kur'ân-ı Kerîm'in ve aile büyüklerinin ellerinin benzer şekilde öpülüp başa götürüldüğü hatırlanmalıdır. Edebî metinlere de yansıdı̆̆ 1 görülen bu davranışın, yaşama sunduğu katkı için ekmeği kutsama ve ona 
şükranlarını sunma anlamına geldiği düşünülebilir. Bağdatlı Rûhînnin aşağıdaki beytinde, günümüz insanının da iyi bildiğ ${ }^{22}$ bu ritüele gönderme yapılmaktadır. Şairin kurduğu benzerlik ilişkisi içerisinde bedendeki "dâğ"lar (yara) şekli ve kokusu dolayısıyla ekmeğe benzetilmiştir. Kimsesiz âşı, gümüş bedenli sevgilinin vücudundaki amber kokulu "dâğ"ları öpme isteğini, "ekmeğin öpülmesi” ritüeli üzerinden meşrulaştırmaya çalışmaktadır ${ }^{23}$ :

Kurs-ı anberdür o sîmîn-bedenün dâgları

Öpdürürse n'ola bî-keslerine nân öpilür [Bağdatlı Rûhî Dîvânı, G 333/2 (Ak, 2001: I/526)]

\section{Yokluk/Kitlık}

Ekmeğe atfedilen bu kutsiyetin bir sebebi de yaşanan kıtlıklardır. Bazen bütün bir şehri etkileyecek derecede geniş çaplı olan bu kıtlıklar, büyük sıkıntılara neden olmuştur. Bu gibi dönemlerde ekmek insanların tek besin kaynağı olmuştur. Ancak ekmeğin de bulunmadığı ya da kalitesinin düşük olduğu dönemlerde insanların sıkıntısı daha da artmıștır ${ }^{24}$. Lebîb, büyük kitlı̆̆ın (kaht-1 a'zam) halk üzerindeki etkilerini anlatmak üzere 1171/17157-58 yılında Vezir Râgıb Mehmed Paşa'ya yazdığı arz-1 hâlde yiyecek bulamayan insanların birbiri ardına ekmeğe hasret olarak ölüp gittiğini, açlıktan ölen insanların cesetleriyle Diyarbakır'ın savaş alanına döndügünü söylemektedir.

Kırılmakda bir uçdan hasret-i nân ile pey-der-pey

Kazâay cenge dönmüş Âmid'in lâsseyle her câyı [Lebîb Dîvânı, Tr.71/21 (Kurtoğlu, 2017:271)

Taşlıcalı Yahya Bey'in 1533-1535 yıllarındaki sefer sırasında yaşanan açlı̆̆ anlattığı şiirinde, kıtlıkta insana kuru ekmeğin şekerden daha tatlı geldiği ve

${ }^{22}$ Günümüzde daha ziyade yere düşen ya da yerde bulunan ekmeğin alınması hatta öpülerek kenara -mümkünse yüksek bir noktaya- konulması ve hayvanlar tarafından yenilmeye müsait hale getirilmesi söz konusudur.

${ }^{23} \mathrm{Bu}$ söylem ayrıca halk arasında -özellikle çocukluk çağında- acıyan yerin öpülmesi uygulamasını da hatırlatmaktadır.

${ }^{24}$ Bu konuda bir örnek olması açısından İstanbul'da uzun zamandan beri yaşanan ekmek sıkıntısı ve III. Selîm'in bu sorunun çözümü için gösterdiği çabalar için bk. Tızlak, 2010. Ayrıca II. Bâyezîd'in (bk. Kanunname-i İhtisab-ı Bursa, 2013: 1-2) ekmeğin fiyatını düşürmeye ve kalitesini arttırmaya yönelik bazı önlemler almış olması, Osmanlı döneminde zaman zaman ekmekle ilgili çeşitli sıkıntılar yaşandığını göstermektedir. 
açlık dönemlerindeki yokluk psikolojisinin insanı hırslı hale getirdiği anlatılmaktadır. Bu durumu anlatmak için de ekmeğini kimseyle paylaşmayıp yalnız yemek söz konusu edilmiştir.

Ol dem kanı ki şekere yok idi iştihâ

Gurbetde âdem kurı etmek olur şeker

Güc ile çıkdı subha ilenc aldı var ise

Hirsindan etmeğini yalınuz yidi kamer [Yahya Dîvânı, K25/13-

14 (Çavuşoğlu, 1977:106)]

Osmanzâde Tâib de aşağıdaki beytinde yokluğu bir başka boyutuyla dile getirmiştir. Söz konusu beyitte fakir birinin veba hastalığı sonucu koltuğunun altında çıan şişliği "somun" zannederek sevindiği belirtilmiştir:

Koltuğunda somun sanup sevinir

Birfakîr mübtelâ-yı vebâ $\quad$ [Osmanzâde Tẩib, K3/21 (Yatman, 1989: 42)]

\section{Beddua/Bir Parça Ekmeğe Muhtaç Olmak}

Kitlık dönemlerinde yokluğu tecrübe etmiş insanlar için ekmek sadece bir besin maddesi olmaktan çıarak bireysel ve toplumsal barışın, huzurun, refahın göstereni hâline gelir. Kazandığı bu anlamla ekmeğin yokluk ya da kıtllğı zengin-fakir herkes için korkulası bir durum olur. Öyle ki bu çerçevede haksızlığa uğradığını düşünen insanlar, zulmün kaynağı olarak gördükleri kişilerin "bir parça ekmeğe muhtaç olması" için beddua edegelmişlerdir. Burada en ağır ceza olarak ekmek yoksunluğunun görülmesi, konumuz açısından dikkat çekicidir. Rezmî̀nin aşağıdaki beytinde ümit tohumlarını ayağının altında ezip çiğneyen sevgili karşısında yapacak hiçbir şeyi kalmayan aşığın son çare olarak Allah’a sığınması söz konusu edilmiştir. Beyitte -yukarıda da değinildiği üzeremahrumiyete/yokluğa sebep olacağı endişesiyle nimete saygısızlık etmekten çekinme anlayışı da görülmektedir. Şair, âşığın ümit tohumu ile ekmeğin hammaddesi olan buğday taneleri arasında ilgi kurmuştur. Nasıl ki nimete yapılan saygısızlık cezalandırılırsa, sevgili de manevi değeri yüksek olan ümide/aşka saygısızlık ettiği için en ağır şekilde cezalandırılmayı hak etmiştir. Rezmînnin bu saygısızlık için reva gördüğü ceza, Allah'ın sevgiliyi "bir ekmeğe muhtaç" hâle getirmesidir: 
Tohm-ı ümmî̀üm benüm pâ-mâl ider Rezmî o yâr

Dilerüm Bârî anı muhtâc ide bir ekmeye [Rezmî Dîvânı, G430/5

(Gürbüz, 2012: 323)]

\section{Vefa/Tuz Ekmek Hakkı}

Mesut Şen, “Tuz Kelimesi Üzerine” isimli çalışmasında "tuz” kelimesinin Türk dilinin tarihi içindeki seyrini ve kazandığı anlam çeşitliğini toplu bir şekilde değerlendirmiştir. Şen, “Türkiye Türkçesinde tuzla ilgili deyimlerden olan 'nimet, ihsan' anlamındaki tuz ekmek, 'iyiliğe nankörlükle karşılık veren' anlamındaki tuz ekmek haini, 'minnet, şükran borcu' anlamındaki tuz ekmek hakkı gibi tabirlere tarihî metinlerde de rastlamak mümkündür.” diyerek çeşitli metinlerden hareketle bu tespitlerini örneklendirmiştir ${ }^{25}$. Taradığımız metinlerde bunlardan "tuz ekmek hakkı" deyiminin kullanıldığı görülmüştür.

Bosnalı Sâbit, sevgilinin kaybolup giden güzelliğine ağıt yaktığı aşağıdaki beytinde sevgilinin güzelliği ile aşığı birbirinden ayrılan iki dost olarak tasavvur etmiştir. Vedalaşan bu iki dost üzerinden de birlikte tuz ekmek yiyen kişilerin birbirlerine vefa göstermeleri, veda zamanı geldiğinde de helalleşmeleri gerektiğine vurgu yapmıştır:

Ne dadı kaldı ne tuzı hân-ı melâhatun

Nân ü nemek yidük bize itsün helâl hat [Sâbît Dîvânı G181/4 (Karacan, 1991: 440)]

Kutadgu Bilig'de ancak cömert ve gözü tok insanların tuz ekmek hakkını da bilen kişiler olabileceği belirtilmiştir:

Negü tir eşitgil közi tok kişi

Tuz ekmek idisi akı er başı (1191)

[Gözü tok, başkaları üzerinde tuz ekmek hakkı olan cömertlerin namlısı ne der dinle. (Şen, 2004: 18)]

Ancak çoğu insan hırslı ve açgözlü olduğu için vefa duygularına da sahip değildir. Esîrî, aşağıdaki beyitlerde dostlarının tuz ekmek hakkını unutarak kendini terk ettiklerini ve sonunda düşman olduklarını söylemektedir. $\mathrm{Bu}$ durumdan yakınan şair, tuz ekmek hatırını gözetecek dostlara duyduğu özlemi de dile getirmiştir:

${ }^{25}$ Tuz ekmek hakkı için ayrıca bk. Samancı, 2013:76-77. 
Kime dostluk eyler isen âkıbet düşmen olur

Nân nemek hakkın gözedür dost ile yâr kalmadı [Esîrî,

Sergüzeştnâme, 1037 (Kutlar Oğuz vd. 2018: 138)]

Senden ayru kimseden dermân yok

Nân nemek hakkın ferâmûş etdiler yoldaşlarum [Esîrî, Dîvân-ı

Firâk-ı Esîrî, G83/4 (Kutlar Oğuz vd. 2018: 400)]

Sahip olduğu meziyetler sebebiyle vefalı olmak en çok insanoğluna yakışırken bencil hislerine yenik düşerek vefasızlığı tercih eder. Hâlbuki hayvanlar bile bu konuda insanlardan daha iyidir. Seyf-i Sarâyî, köpeğin bile vefa ve minnet duygularına sahip olduğunu, bu sebeple kovulsa dahi "tuz ekmek hakkına" riayet ederek gitmeyeceğini belirtir:

Tuz itmekni unutmas kelb kere yüz

Kovar bolsan yana kaytarmas ol yüz [Sarâyî, Gülistân Tercümesi, 349/1-2 (Karamanlıŏlu, 1978: 174)]

[Tuz ekmek hakkını, yine minnet borcunu, köpek bile unutmaz ki yüz defa kovsan dahi yine senden yüz çevirmez. (Şen, 2004: 22)]

\section{Kesret/Dünya Bağı}

Buraya kadar verilen bütün örneklerde ekmeğin yaşamın devamını sağlayan ve en kolay ulaşılan yiyecek olması hasebiyle değerli görüldügü hatta kimi zaman kutsandığı görülmektedir. Erzurumlu İbrahim Hakkı’nın aşağıdaki beytinde diğer bütün örneklerin aksine dolaylı da olsa ekmeğin olumsuzlandığı görülmektedir. Tasavvufî anlayışa göre insan bedeni, dünyayı temsil ederken ruhu da ahireti temsil eder. Sadece beden ve ruhun kendisi değil, onlarla ilgili bütün her şey bu sembolizmin bir parçasıdır. İbrahim Hakkı, beden gibi bedeni besleyen ekmeğe de insanı dünyaya bağlaması nedeniyle olumsuz bir anlam yüklemiştir. Şair, ekmeği "yemek (yenilen her şey)" anlamıyla kullandığı bu beyitte, okuyuculara/saliklere tenin/bedenin ve ruhun temizlenmesi için ekmek -yani yemek- yememeleri, onun yerine oruç tutmaları tavsiyesinde bulunmaktadır:

Savm ile ten ü cânı pâk eyle yeme nânı

Tolsun mey-i rûhânî tâ mest ola hep eczâ [İbrahim Hakkı Dîvânı, G11/4 (Külekçi ve Karabey,1997: 147)] 


\section{Sonuç}

İnsanlık tarihiyle birlikte ortaya çıkmış olan ekmek, bütün zamanlarda ve bütün toplumlarda -üstelik benzer pratiklere sahip şekilde- karşımıza çıkar. Sofraların bu vazgeçilmez unsurunu gerçek anlamıyla "yufka, k/girde, tandır ekmeği, bazlama, somun, çörek" gibi kelimeler ile metinlerde görmekteyiz. Bazı örneklerde çorbanın yanında ya da peynirin yanında çeşitli ekmek türlerinin isimleri zikredilmesi de söz konusudur.

Bunların yanı sıra ekmeğe çeşitli anlamlar yüklenmiş ve ekmek simgesel anlamlarıyla metinlere girmiştir. Rızkı verenin Allah'tan başkası olmadığı, başkasının ekmeğine el uzatmanın haram olduğu, aza kanaat etmenin çoğu istememenin, helal lokma yemenin önemli birer ölçüt olduğu, kuru ekmeğin insana yettiği ve ekmeğin helalinden kazanılması yolunda zor da olsa çalışmak gerektiği gibi uyarı mahiyetindeki anlamlarına ek olarak ekmeğin yoksulluk alameti sayıldığı, bir parça ekmeğe muhtaç kalma bağlamında beddua için kullanıldığı, tuz ekmek hatırında olduğu gibi vefa duygularını anlatıldığı örnekler de mevcuttur. 


\section{Kaynakça}

Ak, Coşkun (2001). Bağdatlı Rûhî Dîvânı (Karşılaştırmalı Metin). IIC. Bursa: Uludağ Üniversitesi Yay.

Aksoyak, İsmail Hakkı (2018). Gelibolulu Mustafa Âlî Dîvânı. Ankara: KTB Yay.

Atalay, Besim (2006). Kâşgarlı Mahmûd, Dîvânu Lugâti't-Türk- I. Ankara.

Başpınar, Fatih (2011). “Basîrînin Bengînâme Adlı Eseri”. Turkish Studies 6 (3): $567-576$.

Başpınar, Fatih (2013). Garâmî- Dîvân. İstanbul: Yedirenk Yay.

Bilkan, Ali Fuat (1997). Nâbî Dîvânı. İstanbul: MEB Yay.

Caferoğlu, Ahmet (1993). Uygur Türkçesi Sözlüğü, İstanbul.

Canan, İbrahim (1988). Kütüb-i Sitte, Hadis Ansiklopedisi. XVIII C. Ankara: Akçă̆ Yay.

Clauson, Sir Gerard (1972). An Etymological Dictionary of Pre-Tirteenth Century Turkish. Oxford.

Çakır, Zehra Vildan (1998). Hevâŷ̀ (Abdurrahman, Kubûrî-zâde) Dîvâni’nın Tenkidli Metni ve İncelemesi). Yüksek Lisans Tezi. Edirne: Trakya Üniversitesi.

Çavuşoğlu, Mehmed (1977). Yahyâ Bey, Dîvan (Tenkidli Basım). İstanbul: İstanbul Üniversitesi Edebiyat Fakültesi Yay.

Emecen, Feridun (1996). "Fodula". İslam Ansiklopedisi. C. XIII. İstanbul: TDV Yay. 167-170.

Erünsal, İsmail (2018). Tâcîzâde Cafer Çelebi, Dîvân. Ankara: KTB Yay. https://ekitap.ktb.gov.tr/TR-211662/taci-zade-cafer-celebidivani.html [Erişim Tarihi: 03.08.2019]

Genç, Reşat (1982). “XI. Yüzyılda Türk Mutfağı”. Türk Mutfağ1 Sempozyumu Bildirileri. Ankara: KTB Yay. 57-68.

Gürbüz, Mehmet (2012). Safiye Sultanzâde Mehmed Rezmî, Dîvân. Ankara: Grafiker Yay.

Kabak, Turgay (2013). “Trabzon-Akçaabat'taki Geleneksel Fırıncilık ve Ekmek Yapım Teknikleri Üzerine Halkbilimsel Bir İnceleme". Dünden Bugüne Akçaabat Sempozyumu (26-28 Nisan 2013). 
Kahraman, Seyit Ali ve Yücel Dağlı (2003). Günümüz Türkçesiyle Evliya Çelebi Seyahatnâmesi. C. I (2. Kitap). İstanbul: YKY.

Kanunname-i İhtisab-ı Bursa. Ankara: TSE.

Kaplan, Mahmut (1996). Neşâtî Dîvânı. İzmir: Akademi Kitabevi.

Karacan, Turgut (1991). Bosnalı Alaeddin Sabit, Divan. Sivas: Cumhuriyet Üniversitesi Yay.

Karamanlığlu, Ali Fehmi (1978). Seyf-i Sarâŷ̂, Gülistan Tercümesi (Kitâb Gülistan bit't-türkî). İstanbul: MEB Yay.

Kartal, Ahmet (2000). "Basîrî ve Türkçe Şiirleri”. İlmî Araştırmalar (10): 7796.

Kaya, Bayram Ali (2017). Azmizâde Hâletî Dîvânı. Ankara: KTB Yay. https://ekitap.ktb.gov.tr/Eklenti/56159,azmizade-haletidivanipdf.pdf?0 [Erişim Tarihi: 10.07.2019]

Kılıç, Atabey (2003). "Karnım Açtır Karnım Aç!”. Berceste Aylık Kültür Sanat Edebiyat Dergisi 2(13): 3-6.

Kılıç, Filiz (hzl.) (2018). Âşık Çelebi, Meşẩirü'ş-Şu'arâ. Ankara: KTB Yayınları. http://ekitap.kulturturizm.gov.tr/Eklenti/59036,asikcelebi-mesairus-suarapdf.pdf?0 [Erişim Tarihi: 11.08.2019]

Kobya, Elif Şebnem (2013). "Kutadgu Bilig'de Yiyecek ve İçecek Adları". Turkish Studies 8 (8): 823-833.

Kurtoğlu, Orhan (2017). Lebîb Dîvânı. Ankara: KTB Yay. https://ekitap.ktb.gov.tr/Eklenti/55756,lebib-divanipdf.pdf?0

[Erişim Tarihi: 13.07.2019]

Kuter, Murat (2013). “Ekmeğin Tarihi”. Standart Ekonomik ve Teknik Dergi 52 (615): 41-45.

https://statik.tse.org.tr/upload/tr/dosya/icerikyonetimi/545/161020 14143405-1.pdf [Erişim Tarihi: 09.06.2019]

Kutlar Oğuz, F. Sabiha, Ayşe Yıldız, Tuba Işınsu Durmuş (2018). Dîvân-ı Firâk-ı Esîrî [Sergüzeșt-nâme - Gazavat-nâme - Pend-nâme Dîvân]. Ankara: KTB Yay. https://ekitap.ktb.gov.tr/TR217192/divan-i-firak-i-esiri.html [Erişim Tarihi: 09.06.2019]

Külekçi, Numan (1985). Gani-zâde Nâdirî- Hayatı, Edebi Kişiliği, Eserleri, Divânı ve Şeh-nâmesi'nin Tenkidli Metni. Doktora Tezi. Erzurum: Atatürk Üniversitesi. 
Külekçi, Numan ve Turgut Karabey (1997). Erzurumlu İbrahim Hakkî, Dîvân. Erzurum: Atatürk Üniversitesi Yay.

Ögel, Bahaeddin (2000). Türk Kültür Tarihine Giriş, IV. Ankara.

Özgüdenli, Osman G. ve Ömer Uzunağaç (2014). “Selçuklu Anadolusu’nda Ekmek”. Marmara Türkiyat Araştırmaları Dergisi 1 (1): 43-72.

Samanc1, Özge (2013). “Osmanlı Kültüründe Ekmeğin Simgesel Anlamları”. Yemek ve Kültür (32): 72-77.

Şavkay, Tuğrul (2000). Osmanlı Mutfağı. İstanbul: Şekerbank Yay.

Şen, Mesut (2004). Tuz Kelimesi Üzerine, Tuz Kitabı, İstanbul: Kitabevi, s:17-27.

Öztekin, Ali (1996). Gelibolulu Mustafa 'Âlî, Câmi'u'l-Buhûr Der Mecâlis-i Sûr. Ankara: TTK Yay.

Pakalın, M. Zeki (1983). Osmanlı Tarih Deyimleri ve Terimleri Sözlügü. III C. İstanbul: MEB Yay.

Tarlan, Ali Nihat (1970). Zatî Divanı (Edisyon Kritik ve Transkripsiyon). İstanbul: İstanbul Üniversitesi Edebiyat Fakültesi Yay.

Trzlak, Fahrettin (2010). “III. Selim ve İstanbul'un Ekmek Problemi”. XVI. Türk Tarih Kongresi (20-24 Eylül 2010). VI. Cilt. Ankara: TTK Yay.: 17-35.

Ünsal, Artun (2003). Nimet Geldi Ekine- Türkiye’nin Ekmeklerinin Öyküsü, İstanbul: YKY.

Yatman, Mustafa (1989). Osmanzade Taib Divanı'ndan Seçmeler. Ankara: KB Yay.

Yıldırım, Sinan (2004). Divan Edebiyatında Nazirecilik Geleneği ve Hevâyînin Nazirelerden Oluşan Divanı. Yüksek Lisans Tezi. Elazığ: Furat Üniversitesi.

Yerasimos, Stefanos (2002). Sultan Sofraları, 15 ve 16. Yüzyılda Osmanlı Saray Mutfağı. İstanbul: YKY.

Yılmaz, Kadriye (2017). İbrahim Tirsî ve Dîvânı. Ankara: KTB Yay. https://ekitap.ktb.gov.tr/Eklenti/55911,ibrahim-tirsi-vedivanipdf.pdf?0 [Erişim Tarihi: 08.07.2019]

Zülfikar, Hamza (2012). “Anlamları, Deyimleri ve Çeşitleriyle Ekmek”. Türk Dili 3 (728): 12-17. 